\title{
DNA Polymerase Epsilon Subunit 2
}

National Cancer Institute

\section{Source}

National Cancer Institute. DNA Polymerase Epsilon Subunit 2. NCI Thesaurus. Code C132125.

DNA polymerase epsilon subunit $2(527 \mathrm{aa}, \sim 60 \mathrm{kDa})$ is encoded by the human POLE2 gene. This protein is involved in the replication and repair of chromosomal DNA. 